\title{
Determinants of Customer Satisfaction in the Telecommunication Industry in Ghana: A Study of MTN Ghana Limited
}

\author{
Eric Oduro ${ }^{1}$, Francis O. Boachie-Mensah ${ }^{2}$ \& Gloria K. Q. Agyapong ${ }^{2}$ \\ ${ }^{1}$ Jinijini Senior High School, Jijini-Berekum, Ghana \\ ${ }^{2}$ School of Business, University of Cape Coast, Ghana \\ Correspondence: Gloria K.Q. Agyapong, School of Business, University of Cape Coast, Ghana.
}

Received: July 3, 2018 Accepted: August 21, 2018 Online Published: August 29, 2018

doi:10.5539/ijms.v10n3p101 URL: https://doi.org/10.5539/ijms.v10n3p101

\begin{abstract}
The study examined the determinants of customer satisfaction in MTN Ghana Limited. The variables of concern were customer expectation, relationship quality, perceived value, perceived quality, and customer loyalty. The American Customer Satisfaction Index (ACSI) model was adapted as the main framework for analyzing customer satisfaction. Data for the study came from a systematic random sample of 377 MTN mobile subscribers, employing questionnaires. Two managers of the mobile network were interviewed on issues related to their CRM systems. Multiple regression analyses were used to examine the relationship between customer expectation, relationship quality, perceived value, perceived (product/service) quality, customer loyalty, and customer satisfaction. The results of the multiple regression indicated that significant positive relationship existed between customer satisfaction and perceived (product/service) quality, relationship quality, and customer loyalty, but not for other variables such as customer expectation, customer complaint, and perceived value. The implications are that MTN Ghana should consider the perceptions of customers on product/service quality, the level of relationship quality and loyalty when managing relationships with customers. The company should put measures in place to build and maintain quality relationships with customers, and also improve the quality of products and services offered to customers. Again, there is the need for management to bridge the gap in their perception of relationship quality and that of customers.
\end{abstract}

Keywords: customer expectation, relationship quality, perceived quality, ACSI model

\section{Introduction}

In today's challenging business environment due to increasing competition among firms, changing economic conditions, changing nature of customers' attitude and behavior, and firms trying hard to satisfy customers through the provision of quality products and services, customer satisfaction is becoming more and more important for the survival of many firms. The customer is the core of every business and the capability of a firm to succeed in this competitive environment depends largely on its ability to manage relationships with customers and increase customers' satisfaction level through relationship building.

CRM (Relationship quality) is becoming more and more important in this competitive business environment. The whole concept of CRM is that it aids an organization to tailor specific products or services to each particular customer. In other words, CRM may be used to create a personalized service or offer that will give each and every customer a sense of being cared for, which, in turn, opens up new marketing opportunities based on the preferences and history of the customer. Intimate customer relationships offer organizations many advantages. For instance, Fournier (1998) stated that committed and satisfied customers can be realised organizational assets who are likely to be a source of favourable word-of-mouth referrals and are more resistant to competitor's offers. According to Buttle (2012), an important justification for CRM is that it improves business performance by enhancing customer satisfaction and driving up customer loyalty. Satisfaction increases, since CRM increases customer insights, which allows companies to understand their customers better, create improved customer value prepositions and better customer experiences.

One important service in an economy around the world is telecommunication. The role of the telecommunication industry in the development of a nation can never be underestimated. Telecommunication has a profound impact on a variety of business application and helps improve the quality of service and lowers the costs. In fact, 
telecommunication has changed the nature of competition in all businesses around the world. The telecommunication industry in Ghana has become more and more competitive with players in the industry introducing innovative products and services such as mobile money, teleconferencing facilities, international roaming, various internet packages and the likes, which present telecommunication industries opportunities and threats.

In spite of the proliferation of telecommunication companies in the country in the last few years, there seems to be widespread dissatisfaction with telecommunication network providers in Ghana among users. Currently, there are six telecommunication network providers in the country, which include: Vodafone, MTN, Tigo, Airtel, Glo, and Expresso. Telecommunication network providers in Ghana are battered with frequent interconnectivity problems, call drops, and denial of services, and customers are very disheartened about the poor service quality delivered by these companies (Nimako, Azumah, \& Donkor, 2010). It was of no surprise that Adjetey (2012) doubted whether telecommunication companies in Ghana have policies in place to help them to achieve total customer satisfaction.

For decades, it has been a shared belief that success in the competitive business environment was dependent on a company's ability to create satisfied customers (Parasuraman, Zeithaml, \& Berry, 1985; Reichheld \& Sasser, 1990; Arnold, Reynolds, Ponder, \& Leveg, 2005). In fact, it had been argued by early scholars that the creation of a satisfied customer was the fundamental core of business. Because of the recognized importance of customer satisfaction in the business environment, a number of studies have been conducted on the determinants of customer satisfaction, such as service quality, customer expectation, perceived value, customer loyalty, and perceived product (Parasuraman, Zeithaml, \& Berry, 1988; Anderson \& Sullivan, 1993; ACSI, 2005; Wu \& Ding, 2007; Saleem \& Raja, 2014; Izogo \& Ogba, 2015). However, a number of studies have shown that many customers who switch to other competitors are often satisfied with their prior products and services (Jones \& Sasser, 1995; Oliver, 1999; Reichheld, 1996; McNeilly \& Barr, 2006).

Based on technological advances and given that products and services offered by companies in a particular market may be essentially the same, researchers and managers are acknowledging that the source of competitive advantage is closely related to the quality of long-term relationships with customers (Palmer, 2002; Palmatier, Dant, Grewal, \& Evans, 2006; Rauyruen \& Miller, 2007). Since there is an increasing number of similar products and services in the Ghanaian telecommunication industry and competition among firms escalating, companies now look towards capturing customers on some factors, other than product quality, price, or convenience. For instance, both MTN and Vodafone Ghana offer similar Huawei phones at almost the same prices to customers, and these phones are available at their walk-through service centres. This implies that customer satisfaction might go beyond these factors mentioned above.

According to Brown (2000), in order to satisfy customers, companies must focus on building unique, one-to-one relationship with customers based on individual needs and wants. Therefore, beyond product/service quality and the factors mentioned earlier, there might be another factor which may be a predictor of customer satisfaction in the telecommunication industry, which is Relationship Quality (RQ), a subcomponent of CRM. But the question is, amongst these variables, which one is the better predictor of customer satisfaction? The main objective of the study, therefore, was to determine the role that the above-mentioned variables play in predicting customer satisfaction at MTN Ghana Limited. The specific research objectives were to: establish how customer expectation can affect customer satisfaction at MTN Ghana, ascertain whether relationship quality and customer loyalty can influence customer satisfaction at MTN Ghana limited, determine the effect of perceived value and perceived quality on customer satisfaction at MTN Ghana limited, determine the effect of customer complaint on customer satisfaction at MTN Ghana limited, and assess how MTN Ghana Limited uses CRM to build relationship with customers. The research questions were: How does MTN Ghana Limited build relationships with customers, using its CRM systems? And what factors affect customer satisfaction at MTN? The following hypotheses were set to be tested:

$H_{1}$ : Customer expectation has no direct effect on customer satisfaction;

$H_{2}$ : Relationship quality has no direct effect on customer satisfaction;

$H_{3}$ : Customer perceived value has no direct effect on customer satisfaction;

$H_{4}$ : Perceived product/service quality has no direct effect on customer satisfaction; and

$H_{5}$ : Customer loyalty has no direct effect on customer satisfaction. 
The rest of the paper is organized as follows. The next section reviews the related literature on customer satisfaction and the underpinning theories. This is followed by the methodology, and results and discussion sections respectively. The final section is the conclusion and recommendations of the study.

\section{Literature Review}

\subsection{Customer Satisfaction}

Customer satisfaction has been the subject of considerable research, and has been defined and measured in many ways (Oliver, 1997). Customer satisfaction has become a very important goal for business organizations over the years, and that loyal customers contribute to the profitability of the company as they spend more on the company's product and services (Dimitriades, 2006). Goodman (2009) stated that the term customer satisfaction is difficult to define, since the expectations of customers are ever changing, making it problematic for companies to give a clearly defined path to satisfy these customers. However, Buttle (2012) defined customer satisfaction as the customer's fulfilment response to a customer experience, or some part thereof. The experience, or some part thereof, component of the definition suggests that the satisfaction evaluation can be directed at any or all elements of the customer's experience, which include product, service, process and any other components of the customer experience. Thus, if customers perceive that their expectations have been met, they are satisfied. If their expectations are underperformed, they are dissatisfied. Indeed, customers do have expectations, and they are able to judge performance. However, sometimes customers' expectations may be met, but the customer will still not be satisfied, and it normally happens when the customer's expectations are too low.

Hill, Roche and Allen (2007) described customer satisfaction as a barometer that forecasts the future behaviour of the customer. Thus, satisfied customers rebound and buy more of the company's offerings. Also, satisfied customers serve as a network to reach other potential customers by sharing experiences (Hague \& Hague, 2016). Tao (2014) posit that it is impossible for a company to grow if the company neglects customers' needs. Achieving customer satisfaction has long been identified as the heart of the marketing concept. Consistent with this, there is strong evidence of positive effects of customer satisfaction on repeat purchase, retention, loyalty, and even profitability (Finn, 2005). In fact, researchers have emphasized that customer satisfaction is key to the success and survival of a business organization, as it has a positive effect on profitability (Merrin Hoffmann \& Penning, 2013; Angelova \& Zekiri, 2011; Novikova, 2009).

\subsection{Expectancy (dis) Confirmation Theory}

Expectancy disconfirmation/ confirmation theory consists of two components: the formation of expectations, and the disconfirmation of those expectations through performance comparisons (Spreng \& Page, 2003; Oliver \& DeSarbo, 1988). According to Churchill and Surprenant (1982), expectations reflect anticipated performance. Oliver (1997) defined expectation as anticipation of future consequences based on prior experience, current circumstances, or other sources of information. Zeithalm, Berry, and Parasuraman (1993) developed a conceptual model of customer service expectations. They found that there were three different levels of customer expectations: desired service, adequate service, and predictive service. However, researchers argued that respondents were often confused when they attempted to distinguish among these three levels of expectation. Notwithstanding that, literature on customer satisfaction suggests that customers' expectations have an impact on satisfaction levels (Bhattacherjee \& Perols, 2008).

As presented by Oliver (1980), customers form expectations of anticipated performance prior to purchase (Buttle, 2012). These expectations serve as the baseline for assessing satisfaction (Oliver, 1993). Interestingly, customers are thought to adapt satisfaction levels to expectation levels in order to avoid the cognitive dissonance that would happen when expectations deviate from satisfaction levels (Staples \& Wong, 2002). Disconfirmation describes the dissonance between an individual's original expectations and observed performance (Bhattacherjee \& Premkumar, 2004). Three types of disconfirmation exist. First, when there are discrepancies between actual performance and individual's expectations, then what is called negative disconfirmation arises. This cognition results in dissatisfaction. Also, when actual performance exceeds expectations, then positive disconfirmation occurs. Simple confirmation exists when actual performance equals expectations (Santos \& Boote, 2003). The majority of the empirical findings supported a positive relationship between expectations and satisfaction (Venkatesh \& Goyal, 2010; Bearden \& Teel, 1983). However, a study by Wu and Ding (2007) showed that customer expectation has no direct positive effect on satisfaction. From the above discussion, it can be hypothesised that:

H1: Customer expectation has no direct effect on customer satisfaction. 


\subsection{Relationship Quality (CRM) and Customer Satisfaction}

In the field of Relationship Marketing, Relationship Quality (RQ) has become an important topic and there is a large body of literature in marketing that has identified the relevance of the quality of relationships between companies and customers (Gronroos, 2011; Lusch \& Vargo, 2011; Gronroos \& Helle, 2012). Relationship quality, according to Palmatier et al. (2006), refers to the overall assessment of the strength of a relationship between two parties. Thus, relationship quality is a measure of the strength of a relationship between a firm (supplier) and a customer (buyer). It measures how strong the relationship is between both parties and, as a result, the buyer may continue to buy even if the customer encounters problems. For some years now, relationship quality has become one of the pillars of relationship marketing (Gummesson, 2002), and the importance attached to relationship quality matches growing reservations about the role of customer satisfaction and service quality (Day, 2003).

Roberts, Varki and Brodie (2003) stress that relationship quality is a better predictor of behavioural intentions than service quality. There are four dimensions that indicate the quality of a relationship: trust, satisfaction, commitment, and affective conflict (Roberts et al., 2003). The trust dimension is divided into credibility and benevolence trust, where the former is based on customers' belief in the firm's sincerity; the latter reflects whether the company is concerned with the welfare of their customers. Satisfaction is a customer's cognitive and affective evaluation, grounded in their personal service experiences with the firm. Commitment is defined as the enduring desire to maintain a valued relationship (Palmatier et al., 2006). Relationship quality, thus, demonstrates that managers must not only focus on the quality of the service they provide, but also on the quality of their customers' relations. Despite the growing number of literature on relationship quality, there continues to be a high degree of ambiguity about its nature and its effect on customer satisfaction (Rauyruen \& Miller, 2007; Ivens \& Pardo, 2007).

According to Jones and Sasser (1995), if a customer is dissatisfied, they may stop being loyal and put an end to the relationship. Given that CRM implementation is often designed to build closer, more value laden relationships with customers, it makes sense for managers to be aware of the quality of the relationships they have with customers (Buttle, 2012). A second hypothesis inferred from the foregoing discussion is:

H2: Relationship quality has no direct effect on customer satisfaction.

\subsection{Customer Perceived Value and Customer Satisfaction}

Customer perceived value is the difference between the prospective customer's evaluation of all the benefits and all the costs of an offering and the perceived alternatives (Kotler et al., 2009). Karolina (2013) explained that perceived value is a measure of quality relative to price paid. An early pioneer in the study of equity, Homans (1961), stated that the essence of equity was contained in a "rule of justice." In fundamental terms, equity is an evaluation of fairness, rightness, or deservingness that customers make in reference to what others receive (Oliver 1997; Wu \& Ding, 2007). In the satisfaction literature, equity theory considers the ratio of the customer's perceived outcome/input to that of the service provider's outcome/input (Oliver \& DeSarbo, 1988). Bolton and Lemon (1999) extended this concept to the perspective of perceived value. They declared that equity referred to customers' evaluation of the perceived sacrifice (input) of the offering (outcome). Therefore, the value customers perceive they are receiving can have an impact on their satisfaction level (Yang, 2001). According to Monocha, Dawson, Blandford, and Millard (2005), a positive customer perceived value may bring customers back to make another transaction. The third hypothesis for the study inferred from the foregoing discussion is:

H3: Customer perceived value has no direct effect on customer satisfaction.

\subsection{Perceived (Product/Service) Quality and Customer Satisfaction}

Perceived quality is a measure of the customer's evaluation through recent consumption experience of the quality of a company's product and service (Karolina, 2013). In this challenging and constantly changing business environment, offering a superior product or service quality, through a strong focus on customer, is one of the key factors enabling organizations to gain a lasting competitive advantage (Chiara, 2007). According to Ladhari (2011), organizations are now trying to focus more on a continuous monitoring and evaluation of service quality, involving various innovative offerings and service developments that have a direct influence on customers' service experiences. Literature regarding service quality has demonstrated a correlation between behavioural intention and service quality, where the perceived service quality influences the behavioural intentions and can signal whether or not a customer will defect (Zeithaml, Berry \& Parasuraman, 1985). Cronin and Taylor (1992) examined the relationships among service quality, customer satisfaction, and purchase intention. The results of correlation analysis suggested that service quality was an antecedent of customer 
satisfaction, and service quality had less effect on purchase intentions than did customer satisfaction. Anderson and Sullivan (1993) also posit that, based on empirical findings in service quality and satisfaction literature, service quality is one of the antecedents of satisfaction (Reidenbach \& Sandifer-Smallwood, 1990). Coner and Gungor (2002) as well as other researchers suggest that quality of product and service is directly related to customer satisfaction and leads to the loyalty of the customer (Coner \& Gungor, 2002; Cronin \&Taylor, 1992, 1994). A fourth hypothesis inferred from the discussion is:

H4: Perceived product/service quality has no direct effect on customer satisfaction.

\subsection{Customer Loyalty and Customer Satisfaction}

Customer loyalty is a deeply held commitment to re-buy or re-patronise a preferred product or service consistently in the future, despite situational influences and marketing efforts having the potential to cause switching behaviour (Oliver, 1997). Loyalty is about earning people's enthusiastic commitment to a relationship that will improve their lives over the long term. Loyalty is about the future, and not the past. The cost of recruiting a new customer is more than retaining an existing one (Gallo, 2014). So it is of no surprise when Thomas and Tobe (2013) emphasize that loyalty is more profitable. That is, the ability of a company to win customers and to keep them coming back is a key to its success. According to Yoo and Bai (2013), loyal customers are less likely to be persuaded by a competitor's brand just because of price and other special promotions; they have the ability to bring in new customers through word-of-mouth, and they are less expensive to maintain. However, it should be observed that customer repurchases from a company regularly does not in itself mean the customer is loyal. According to Derek (2004), the customer may purchase repeatedly from a company for a number reasons. Customer loyalty is frequently exercised as a conscious evaluation of the price/quality ratio or the willingness to pay a premium price or, alternatively, price indifference (Zeithaml, Berry, \& Parasuraman, 1996).

Loyalty is a consequence of customer satisfaction; satisfaction is primarily influenced by the value of services provided to customers. It is, however, also suggested that satisfaction may signal the beginning of loyalty, but cannot guarantee it, especially in the short run (Gungor, 2007). The fifth hypothesis for the study that resulted from the foregoing discussion is:

H5: Customer loyalty has no direct effect on customer satisfaction.

\subsection{Conceptual Framework Developed for the Study}

The conceptual framework for the study was adopted and modified from the empirical study by American Customer Satisfaction Index model (2008) depicted in Figure 1.

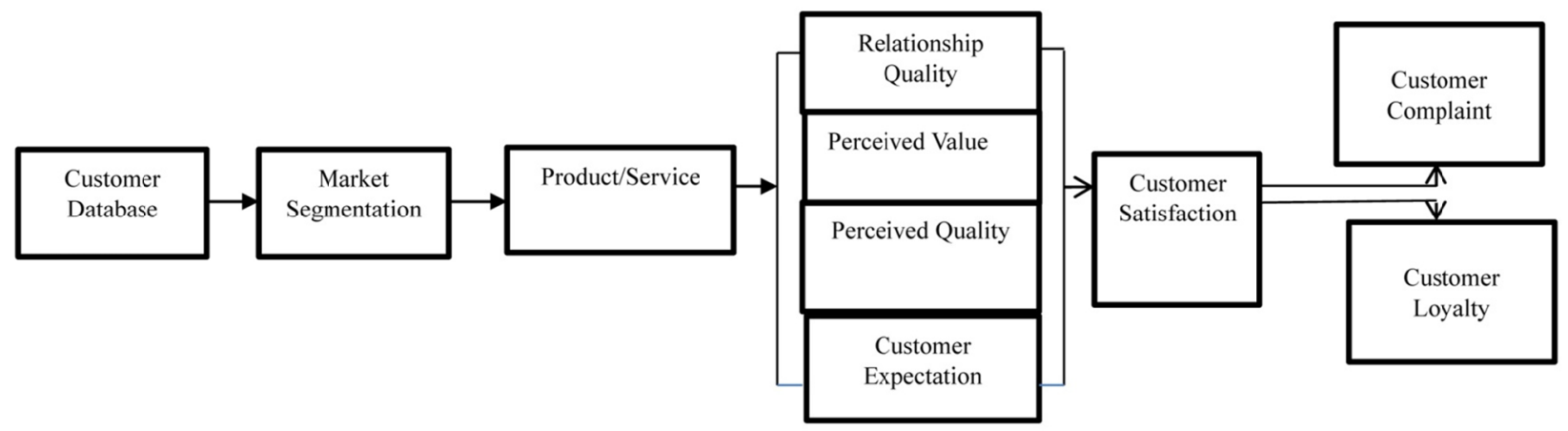

Figure 1. Customer relationship management and customer satisfaction model

Source: Adapted from the ACSI Model (2008).

The framework indicates that implementation of CRM is a multi-step process that involves some basic components. The first key component is the creation of customer database, which contains all relevant information, including descriptive information (such as psychographics and demographics), transaction history, and customer contact information (Winer, 2001). The customer database can serve as a competitive advantage if it is maintained correctly, since it is the initial step in customer relationship management (Espinoza \& Rust, 2006). Since technology has enabled firms to collect and store a large amount of information to build customer database, the next step in the CRM process is the analysis of this information. Based on the knowledge acquired 
from the customer database, the company can then segment the market and provide each segment with products/services that meet the respective needs of customers in order to satisfy them. This innovative one-to-one marketing concept encourages firms to address individual customer needs and to analyse lifetime customer value. This customer database enables an organization to maintain quality relationships with customers. The conceptual framework also indicates that customer satisfaction has four antecedents (drivers or causes of satisfaction), which are: perceived quality, perceived value, relationship quality, and customer expectations.

\section{Methodology}

The study was rooted in both quantitative and qualitative model (mixed method approach). The study employed the survey design. The target population for the study was employees and customers of MTN Ghana Limited in the Sunyani Municipality. According to the marketing manager of MTN Ghana Limited in Accra, the customer base of MTN Ghana in the Sunyani Municipality was about 25,650, which constituted the population of the study. The Sunyani branch had staff strength of seventeen employees, including one customer service manager and one regional sales manager. MTN Ghana Limited was chosen, because it was the number one telecommunication network in Ghana with over 55\% market share, according to the National Communications Authority (NCA, 2013). Also, customers of the network company had been complaining about its services.

The study adopted both the probability and non-probability sampling techniques. Specifically, the study employed both purposive and systematic sampling techniques. The purposive sampling technique was used to select two managers within the Sunyani Zone of MTN Ghana Limited. The systematic sampling technique was used to select the customers of MTN Ghana Limited. The systematic sampling technique was used because it is accurate, easily accessible and not containing periodic patterns. Again, with the systematic sampling, actual list (sampling frame) is not always needed; and it has relatively low cost. Also, it is less time consuming; and relatively easy to explain (Saunders et al., 2009). In all, the customer sample size was 377.

The main instruments for data collection were the questionnaire and the interview guide. Basically, the questionnaire was used to collect data from customers. The instrument used was a modified version of the American Customer Satisfaction Index model, which also made use of a 10-point Likert scale. The interview guide, on the other hand, was used to collect data from management of MTN Ghana Limited at the Sunyani Branch.

Also, data were obtained from customers who had been with the MTN Ghana Limited for at least one year. First, the researchers visited the administrative offices of the Sunyani branch of the Company where, through the District Foundation Advisor, documents and literature on the profile of the Company as well as newspaper clippings on media coverage of their customer base were obtained. The entire data collection exercise took place between $10^{\text {th }}$ November, 2014, and $16^{\text {th }}$ March, 2015. The data were collected by the researchers with the help of two research assistants. The Assistants were trained by explaining the topic and purpose of the study, and teaching them how to explain the questionnaire to the respondents, if they had difficulties in answering the questions.

The data collected were sorted, edited, organised and coded. After coding, the data were analysed. Statistical Package for the Social Sciences (SPSS) version 16 was used to run descriptive and factor analysis and the necessary statistical tests for the results. STATA 12 was employed to run the regression analysis. The qualitative analysis involved summarising or condensation of meanings. Summarising involves condensing the meaning of large amounts of text into fewer words. That is, the researchers produced a summary of the key points that emerged from undertaken this activity. The condensation of meaning also enabled the researchers in identifying relationships between themes.

\section{Results and Discussion}

\subsection{Descriptive Statistics of Customer Satisfaction Factors}

Several factors are known to affect customer satisfaction. However, this study looked at only six, which included: customer expectation, perceived value and perceived quality, relationship quality, customer complaint and customer loyalty. Customer satisfaction and its factors have been analysed below. 
Table 1. Descriptive statistics of customer expectation

\begin{tabular}{|c|c|c|c|c|c|}
\hline Customer Expectation & $\mathrm{N}$ & Mean & Std dev & t statistic & $\begin{array}{l}\text { Sig } \\
\text { (2-tailed) }\end{array}$ \\
\hline High expectations for overall quality service & 344 & 6.40 & 2.60 & 9.96 & $0.000^{*}$ \\
\hline product/service should meet personal requirements & 344 & 5.74 & 2.68 & 5.13 & $0.000 *$ \\
\hline No Service failure & 344 & 5.97 & 2.55 & 7.04 & $0.000 *$ \\
\hline
\end{tabular}

*denotes significant at $5 \%$.

Table 1 shows the expectation of customers before subscribing to MTN. The mean scale values and standard deviations for the customer expectation scale items ranged from 5.74 to 6.40 and 2.55 to 2.68 respectively. On the 10-point Likert scale, ranging from 0 to 10,5 is the scale midpoint, indicating a neutral position (which shows customer indifference) with values below it approximating no agreement and values above it approximating strong agreement (Field, 2005). Three variables were used to measure customer expectation with their mean responses significantly above 5 , as confirmed by the t-statistics and the p-values. Therefore, on the basis of the Likert scale, majority of respondents' (customers') expectation prior to MTN subscription appeared to be fairly high, and, as indicated by Churchill and Surprenant (1982), expectations reflect anticipated performance (Oliver, 1997). This result is not surprising, as MTN is the leading communications network in Ghana with a wide range of products and services, huge capital base, and has more subscribers than any other telecommunications network in the country. Therefore, customers expect them to give better and high quality service tailored to suit their needs.

Table 2. Descriptive statistics of relationship quality

\begin{tabular}{lccccl}
\hline Relationship Quality & N & Mean & Std dev & t statistic & $\begin{array}{l}\text { Sig } \\
\text { (2-tailed) }\end{array}$ \\
\hline Satisfied with relationship with MTN & 344 & 5.89 & 2.53 & 6.51 & $0.000^{*}$ \\
Non-commitment to the relationship with MTN & 344 & 5.47 & 2.43 & 3.59 & $0.000^{*}$ \\
No Trust & 344 & 5.11 & 2.46 & 0.83 & 0.405 \\
Cognitive dissonance & 344 & 5.18 & 2.52 & 1.33 & 0.180 \\
\hline
\end{tabular}

*denotes significant at $5 \%$.

In order to reveal the extent of relationship quality between MTN and its subscribers, respondents were asked to indicate their agreement to four statements, using the 10-point Likert scale, as depicted in Table 2. The mean scale values and standard deviations for the responses varied from 5.11 to 5.89 and 2.43 to 2.53 respectively. Table 2 revealed that majority of respondents fairly agreed that they were not satisfied with their relationship with MTN, given that the t-statistic confirmed the mean scale value to be significantly above 5 at alpha level of 5 per cent.

Again, the results in Table 2 revealed that the mean scale value for 'commitment to the relationship with MTN' is significantly above the mid-point, which suggests that respondents are not committed to their relationship with MTN. This further suggests that MTN was not doing well to manage the relationship between it and the customers. The fact that customers of MTN Ghana Limited were not satisfied with their relationship with the company was an indication that the company was losing out on the many benefits they could enjoy from maintaining quality relationship with customers. This is so because, according to Jones and Sasser (1995), when customers are dissatisfied with their relationship with a company, they stop being loyal and, eventually, put an end to the relationship.

Table 3. Descriptive statistics of perceived value

\begin{tabular}{lccccl}
\hline Perceived Value & $\mathrm{N}$ & Mean & Std dev & $\mathrm{t}$ statistic & $\begin{array}{l}\text { Sig } \\
(2 \text {-tailed })\end{array}$ \\
\hline Fair price & 343 & 5.20 & 2.63 & 1.41 & 0.159 \\
Value for money & 343 & 5.49 & 3.52 & 2.59 & $0.010^{*}$ \\
\hline
\end{tabular}

*denotes significant at $5 \%$. 
In Table 3, two variables were used to measure perceived value with mean scale values of 5.20 and 5.49 respectively. The standard deviations for these two variables, as indicated in Table 3, are 2.63 and 3.52 respectively. T-statistic for 'fair price' reveals that the mean scale value of 5.20 is not significantly different from 5 , which is the scale mid-point. That is, respondents were indifferent between the two extremes of "no agreement" and "strongly agree". It is clear from this result that MTN Ghana should consider ways and means to better its services to meet the objective of price fairness.

On the other hand, t-statistic for 'value for money' reveals that the mean scale value of 5.49 is significantly above 5 , which indicates majority of respondents fairly equate the quality of service to the price they pay for the services provided by MTN. However, this mean scale value of 5.49 is also not too far from the indifferent scale value of 5, which means that customers of MTN Ghana Limited cannot equate the sacrifice (input) to the offering (outcome). But, according to Yang (2001), the value customers perceive they are receiving can have an impact on their satisfaction level. As posited by Monocha et al. (2005), a fairly high customer perceived value may bring customers back to make another transaction.

Table 4. Descriptive statistics of perceived quality

\begin{tabular}{llcccl}
\hline Perceived Quality & $\mathrm{N}$ & Mean & Std dev & t statistic & $\begin{array}{l}\text { Sig } \\
\text { (2-tailed) }\end{array}$ \\
\hline High quality of service & 344 & 6.11 & 2.55 & 8.10 & $0.000^{*}$ \\
The product/service meets my personal requirements & 344 & 5.72 & 2.45 & 5.43 & $0.000^{*}$ \\
Low service failure & 344 & 5.82 & 2.36 & 6.46 & $0.000^{*}$ \\
\hline
\end{tabular}

*denotes significant at $5 \%$.

From Table 4, three variables were used to measure perceived quality (customers' actual experience with the product/service) of MTN Ghana Limited with mean scale values of 6.11, 5.72 and 5.82 respectively, with t-statistics and p-values confirming that these mean scales are significantly above 5 . The results imply that customers fairly perceive that the service rendered by MTN is of high quality; it meets their personal requirements, and their service does not often go wrong. As suggested by Coner and Gunger (2002), the quality of product or service has direct relationship with customer satisfaction and leads to the loyalty of customers.

Table 5. Descriptive statistics of customer loyalty

\begin{tabular}{|c|c|c|c|c|c|}
\hline Customer Loyalty & $\mathrm{N}$ & Mean & Std dev & t statistic & $\begin{array}{l}\text { Sig } \\
\text { (2-tailed) }\end{array}$ \\
\hline Repeat purchase & 344 & 5.55 & 2.49 & 4.12 & $0.000^{*}$ \\
\hline Recommendations to others & 344 & 5.15 & 2.30 & 1.22 & 0.223 \\
\hline Low switching behaviour & 344 & 5.14 & 2.25 & 1.18 & 0.232 \\
\hline
\end{tabular}

*denotes significant at $5 \%$.

On customer loyalty, respondents were asked to indicate their agreement to three statements on the 10-point Likert scale. The mean scale values for the statements are 5.55, 5.15 and 5.14 respectively, with variability among these items varying from 2.25 to 2.49 , as shown in Table 5. The t-statistic reveals that only repeat purchase is above the neutral point. That is, respondents revealed that they are likely to buy MTN products/services again and, as Zeithalm et al. (1996) posit, these customers are committed to the relationship and are, therefore, willing to pay premium price. They are, however, not likely to recommend the network to others and may switch when they are highly dissatisfied.

Table 6. Descriptive statistics of customer satisfaction

\begin{tabular}{llllll}
\hline Customer Satisfaction & $\mathrm{N}$ & Mean & Std dev & $\mathrm{t}$ statistic & $\begin{array}{l}\text { Sig } \\
(2 \text {-tailed })\end{array}$ \\
\hline Satisfaction with the Company & 344 & 6.01 & 2.69 & 7.01 & $0.000^{*}$ \\
The product has fallen short of my expectation & 344 & 5.41 & 2.52 & 2.99 & $0.000^{*}$ \\
\hline
\end{tabular}

*denotes significant at $5 \%$. 
In order to identify whether or not customers of MTN are satisfied with their product/service, respondents were asked to indicate their agreement to the statements in Table 6, using the 10-point Likert scale, ranging from 0 to 10. For 344 respondents, the mean scale response values for the respective statements are 6.01 and 5.41, which are significantly above the scale mid-point 5 , given the t-statistics. The results, as shown in Table 6 , reveal that customers of MTN were not satisfied with the service the company rendered to them and the product had fallen short of their expectation. Customer satisfaction is closely linked to quality customer relationship.

\subsection{Regression Analysis of the Hypothesised Model of Customer Satisfaction}

The study focused on how relationship quality (CRM) can affect customer satisfaction, without overlooking other variables, such as customer expectation, perceived quality, and customer complaint and customer loyalty. This section presents findings from the regression analysis on the main variables. These results have been presented in Table 7 . The table shows the model summary, with the calculated value of $\mathrm{R}^{2=} 0.523$, confirming that the three main factors, namely perceived quality, relationship quality, and customer loyalty, reaching significant level, explain 52 per cent of the variation in the level of customer satisfaction of the sample. The value of the Adjusted $\mathrm{R}^{2}=0.511$ is the value of the coefficient of multiple determination adjusted for degrees of freedom. It ensured that when adjusted for degrees of freedom, the three variables, namely perceived quality, relationship quality, and customer loyalty, explain 51 per cent of the variation in the level of customer satisfaction of the sample.

Table 7. Regression model for customer satisfaction

\begin{tabular}{lllll}
\hline Customer Satisfaction & Beta & $\begin{array}{l}\text { Standard } \\
\text { Error }\end{array}$ & T & Sig \\
\hline Constant & 1.246 & 0.516 & 1.554 & 0.122 \\
Customer Expectation & -0.006 & 0.057 & -0.099 & 0.921 \\
Perceived Quality & 0.365 & 0.070 & 5.238 & $0.000^{* * *}$ \\
Relationship Quality & 0.348 & 0.066 & 5.296 & $0.000^{* * *}$ \\
Customer Loyalty & 0.146 & 0.070 & 2.086 & $0.038^{* *}$ \\
Customer Complaint & -0.134 & 0.231 & 0.581 & 0.562 \\
\hline
\end{tabular}

F stat (prob) $=43.814(0.000)$

$\mathrm{R}^{2}=0.523$ Adj. $\mathrm{R}^{2}=0.511$

Linktest hat: $\mathrm{P}>|\mathrm{z}|=0.001$ hatsq: $\mathrm{P}>|\mathrm{z}|=0.587$

$* * *$ denotes significant $1 \%$.

$* *$ denotes significant $5 \%$.

The F-statistic ( $\mathrm{F}=43.814$, Prob.F-stat $<0.000)$ shows that there is strong and significant relationship between customer satisfaction and its factors. These figures provide evidence of model fit, indicating particularly that the regression model fitted the data reasonably well. On the individual factors, perceived quality (beta $=0.365, \mathrm{p}<$ $0.000)$, relationship quality $($ beta $=0.348, \mathrm{p}<0.000)$ and customer loyalty (beta $=0.146, \mathrm{p}<0.038)$ are positively and significantly related to customer satisfaction. That is, according to the results, there is an indication that perceived product/service quality directly influenced customer satisfaction (beta $=0.365, \mathrm{p}<$ 0.000). This predicted result supports the empirical findings that perceived product/service quality is one of the antecedents of customer satisfaction (Cronin \& Taylor, 1992; Anderson \& Sullivan, 1993; Reidenbach \& Sandifor-Smallwood, 1993). The result also supports Coner and Gunger's (2002) assertion that quality of product and service is directly related to customer satisfaction. This indicates that a unit decrease in perceived quality can result in a corresponding decrease in customer satisfaction by 0.365 units. That is, the level of customer satisfaction is decreased significantly following any negative perception regarding the quality of the services that are being delivered.

Again, the study found significant positive relationship between relationship quality and customer satisfaction, and that relationship quality had a direct significant effect on customer satisfaction (beta $=0.348, \mathrm{p}<0.000)$. Though, in the field of relationship marketing, relationship quality has become an important and popular topic, there seem not to be any empirical findings on relationship quality as a predictor of customer satisfaction. Notwithstanding this, a study by Roberts et al. (2003) stressed that relationship quality is a predictor of behavioural intentions. This is also an indication that a unit decrease in relationship quality between MTN and its subscribers can result in a corresponding decrease in customer satisfaction by 0.348 units. This means that improvement in relationship quality is a key in maintaining customers and increasing customer satisfaction as a whole. 
Moreover, the study found significant positive relationship between customer loyalty and customer satisfaction, and that it also has a direct significant effect on satisfaction. A study by Coner and Gunger (2002); Cronin and Taylor (1992); and Dabholkar, Shepherd and Thorpe (2000) indicated that loyalty is one of the consequences of satisfaction. However, the current study showed that customer loyalty is also a predictor or antecedent of satisfaction (beta $=0.146, \mathrm{p}<0.038)$. Again, the results in Table 7 revealed that a unit increase in customer loyalty has the tendency to increase customer satisfaction by 0.146 units. Analysis of the regression coefficients $($ beta $)$ suggests that while customer loyalty (beta $=0.134)$ and relationship quality $($ beta $=0.348)$ are both strongly linked to customer satisfaction, the impact of perceived quality $($ beta $=0.365)$ is relatively greater

However, customer expectation and customer complaint were found to have no significant positive relationship with customer satisfaction. That is, customer satisfaction could not be explained by customer expectation and customer complaint. This unpredicted result of customer expectation not having a direct influence on customer satisfaction does not support the empirical findings of a positive relationship between expectation and satisfaction identified by Venkatesh and Goyal (2010), and Bearden and Teel (1983). However, a study by Wu and Ding (2007) supports the finding of the current study that customer expectation has no direct effect on customer satisfaction.

In order to have an insight into whether MTN Ghana manages its relationship with customers well to ensure that relationship quality is achieved, two managers, namely customer care manager and regional sales manager, were interviewed. Since relationship is built by knowing something about the parties involved, these managers were asked whether MTN Ghana kept database of its customers, using a CRM system. A 'yes' answer was given to this question. This shows the importance that MTN Ghana attaches to CRM. As Winer (2001) notes, customer database is the necessary first step to a complete CRM process.

According to the managers, the database contained demographic, psychographic and, sometimes, purchase history of their customers. The managers also stressed that the database was also used to contact customers on whether, after visiting the office, their needs were addressed, and that their complaints were handled properly and were satisfied with their product/service. In describing the relationship between MTN Ghana and its customers, the customer service manager described the relationship as excellent. However, the regional sales manager rated MTN Ghana's relationship with customers as above average, given the reason that there was still more room for improvement in dealing with customer complaints, in order to achieve total satisfaction of customers.

\section{Conclusion and Implications}

This paper sought to examine customer relationship management and customer satisfaction at MTN Ghana Limited. Building and maintaining relationships with customers and achieving total customer satisfaction are very important in any service delivery organization, especially when competition is very keen in this changing business environment, where customers' demands keep changing day in and out. Based on the empirical results, customer expectation has no significant relationship with customer satisfaction, and this result confirms that customer expectation has no direct positive effect on customer satisfaction. While it is difficult to comprehend why customer expectation did not influence or affect customer satisfaction, it may be that customers in developing countries, such as Ghana, do not form expectations of anticipated performance prior to purchase. Or, as it is known, customers are thought to adapt satisfaction levels to expectation levels in order to avoid the cognitive dissonance that would happen when expectations deviate from satisfaction levels.

Again, based on the empirical results, customer complaint was found to have no significant relationship with customer satisfaction. Thus, the finding confirms that customer complaint has no direct positive effect on customer satisfaction. The empirical result also confirms that customer complaint is not an antecedent of customer satisfaction, but rather a consequence or an outcome of satisfaction. Thus, if a customer is not satisfied with a product/service, the customer will complain and, when the complaint is handled well, the company successfully turns a complaining customer to a loyal customer.

Nevertheless, based on the empirical results, this study concludes that perceived product/service quality, relationship quality, and customer loyalty are the most important determinants of customer satisfaction at MTN Ghana Limited. These results disconfirm the assertion that perceived product/service quality, relationship quality, and customer loyalty have no direct positive effect on customer satisfaction. Rather, perceived product/service quality, relationship quality, and customer loyalty have a direct positive effect on customer satisfaction. In particular, the lower the product or relationship quality, the lower the level of customer satisfaction, and that the more loyal customers are to a particular brand, the greater the level of satisfaction among customers. On the 
other hand, the higher the product or relationship quality, the higher the level of customer satisfaction, and that the less loyal customers are to a particular brand, the lower the level of satisfaction among customers.

A major implication is that because the empirical results showed that customer loyalty determines customer satisfaction, customer loyalty is not just an outcome of satisfaction, but also an antecedent of satisfaction. Thus, loyal customers turn to be satisfied with whatever their brand owners will offer. Again, although relationship quality as a factor has not been tested as a predictor of customer satisfaction, the empirical results showed that, aside perceived product/service quality, relationship quality is a better predictor of customer satisfaction than the other factors.

The empirical results of the study have managerial implications for the telecommunications sector, as a whole, and MTN Ghana Limited, in particular. In managing relationships with customers, telecommunications companies should consider perceptions of product/service quality, the level of relationship quality and loyalty. The study found a significant relationship between perceived product/service quality, relationship quality and customer satisfaction. These variables were also seen as better predictors of customer satisfaction than brand image, which is the goal of many service companies. It is, therefore, important for telecom companies to put measures in place to build and maintain quality relationships with customers, and also improve the quality of products and services offered to customers. Also, to have a better understanding of customer satisfaction, managers must survey customers about perceived product/service quality, relationship quality, and customer loyalty. The research indicated that when customers have negative perceptions about product/service quality and relationship quality, notwithstanding high investments into corporate reputation building and sales promotion, customers would not recommend the company's network to others; they are likely to switch to other companies providing the same services, in order to enjoy quality service.

\section{Suggestions for Future Research}

The use of one municipality as the study area could limit the external validity of the study, making the results unlikely to be generalizable to other areas in the country and to other firms within the same industry. The logic for future researchers is to consider subscribers across the entire country. Also, further attempts at validating the conceptual model could be carried out in other telecommunications industries and service sectors of the Ghanaian economy, such as hotel and restaurant, banking and insurance, and retailing.

\section{References}

Adjetey, E. R. A. (2012). Total quality management in the telecommunication industry in Ghana: A look at customer satisfaction with the Airtel network (Unpublished master's thesis). University of Ghana, Legon, Ghana.

American Society for Quality. (2005). American Customer Satisfaction Index: Methodology Report. University of Michigan Business School.

American Society for Quality. (2008). American Customer Satisfaction Index: Methodology Report. University of Michigan Business School.

Anderson, E. W, \& Sullivan, M. (1993). The antecedents and consequences of customer satisfaction for firms. Journal of Marketing Science, 12(2), 125-143. https://doi.org/10.1287/mksc.12.2.125

Andreassen, T. W., \& Lervik, L. (1999). Perceived relative attractiveness today and tomorrow as predictors of future repurchase intention. Journal of Service Research, 2, 164-172. https://doi.org/10.1177/109467059922004

Andreassen, T. W., \& Lindestad, B. (1998). The effect of corporate image in the formation of customer loyalty. Journal of Service Marketing, 1, 82-92. https://doi.org/10.1177/109467059800100107

Angelova, B., \& Zekiri, J. (2011). Measuring Customer Satisfaction with Service Quality Using American Customer Satisfaction Model (ACSI Model). International Journal of Academic Research in Business and Social Sciences, 1(3), 232-258. https://doi.org/10.6007/ijarbss.v1i2.35

Arnold, M. J., Reynolds, J. E., Ponder, N., \& Lueg, J. E. (2005). Customer delight in a retail context: Investigating delightful and terrible shopping experiences. Journal of Business Research, 58(8), 1132-1145. https://doi.org/10.1016/j.jbusres.2004.01.006

Bearden, W. O., \& Teel, J. E. (1983). Selected determinants of consumer satisfaction and complaint reports. Journal of Marketing Research, 20(1), 21-28. https://doi.org/10.2307/3151408 
Bhattacherjee, A., \& Premkumar, G. (2004). Understanding changes in belief and attitude toward information technology usage: A theoretical model and longitudinal test. MIS Quarterly, 28(2), 229-254. https://doi.org/10.2307/25148634

Bolton, R. N., \& Lemon, K. N. (1999). A dynamic model of customers' usage of services: Usage as an antecedent and consequence of satisfaction. Journal of Marketing Research, 36(2), 171-186. https://doi.org/10.2307/3152091

Brown, S. (2000). From customer loyalty to customer dependency. Customer relationship management. New York: John Wiley \& Sons Canada, Ltd.

Buttle, F. (2012). Customer relationship management: concepts and technologies (2nd ed.). New York: Routledge.

Chiara, G., Nicola, S., \& Giuliano, N. (2007). Customer Experience: An Overview of Experience Components that Co-create Value with the Customer. European Management Journal, 25(5), 395-410.

Cöner, A., \& Güngör, M. O. (2002). Factors affecting customer loyalty in the competitive Turkish metropolitan retail markets. Journal of American Academy of Business, 2(1), 189-195.

Cronin, J. J. Jr., \& Taylor, S. A. (1992). Measuring service quality: A re-examination and extension. Journal of Marketing, 56(3), 55-68. https://doi.org/10.2307/1252296

Day, G. S. (2003). Creating a superior customer-relating capability. Sloan Management Review, 44(3), 77-82.

Derek, R. A., \& American society for quality staff. (2004). Customer Satisfaction Research Management: A comprehensive Guide to Integrating Customer Loyalty and Satisfaction Metrics in the Management of Complex Organizations, 97-100.

Dillman, D. A. (2007). Mail and internet survey: The Tailored Design (2nd ed.). Hoboken: John Wiley.

Dimitriades, S. Z. (2006). Customer satisfaction, loyalty and commitment in service organizations: Some evidence from Greece. Management Research News, 29(12), 782-800. https://doi.org/10.1108/01409170610717817

Drucker, P. F. (1973). Management: Tasks, Responsibilities and Practices. New York: Harper and Row.

Eklof, J. A. (2000). European customer satisfaction index pan-European telecommunication sector report based on the pilot studies 1999. European Organization of Quality and European Foundation for QualityManagement, Stockholm, Sweden.

Espinoza, F., \& Rust, R. (2006). How technology advances influence business research and marketing strategy. Journal of Business Research, 1072-1078.

Field, A. (2005). Discovering statistics, using SPSS for windows. London: Sage Publications.

Fornell, C., Johnson, M. D., Anderson, E. W., Cha, J., \& Everitt-Bryant, B. (1996). The American customer satisfaction index: Nature, purpose, and findings. Journal of Marketing, 60, 7-18. https://doi.org/10.2307/1251898

Gallo, A. (2014). The Value of Keeping the Right Customer.

Goodman, J. A. (2009). Strategy Customer Service: Managing the Customer experience to increase positive word of mouth, build loyalty and maximise profit. New York: AMACOM.

Gronroos, C. (2011). A service perspective on business relationships: the value creation, interaction and $\begin{array}{llll}\text { marketing interface. Industry } & \text { 240-247. }\end{array}$ https://doi.org/10.1016/j.indmarman.2010.06.036

Gronroos, C., \& Helle, P. (2012). Return on relationships: Conceptual understanding and management of mutual gains from relational business engagements. Journal of Business Industry Marketing, 27, 344-359. https://doi.org/10.1108/08858621211236025

Gummesson, E. (2002). Relationship Marketing in the New Economy, Journal of Relationship Marketing, 1(1), 35-57. https://doi.org/10.1300/J366v01n01_04

Gungor, H. (2007). Observing and registering emotional satisfaction of customer contacts for customer satisfaction and loyalty. Amsterdam: Amsterdam University Press. https://doi.org/10.5117/9789056294663

Hague, P., \& Hague, N. (2016). Customer Satisfaction Survey. The customer experience through the customer's eyes. London: Cogent Publication Ltd. 
Hill, N., Roche, G., \& Allen, R. (2007). Customer Satisfaction. The customer experience through the customer'seyes. London: Cogent Publication Ltd.

Homans, G. C. (1961). Social behaviour: Its elementary forms. New York: Harcourt Brace.

Ivens, B. S., \& Prado, C. (2007). Are key account relationships different? Empirical results on supplier strategies and customer relations. Industrial Marketing Management, 36, 470-482. https://doi.org/10.1016/j.indmarman.2005.12.007

Izogo, E. E., \& Ogba, I. E. (2015). Service quality, customer satisfaction and loyalty in automobile repair services sector. International Journal of Quality and Reliability Management, 32(3), 250-269. https://doi.org/10.1108/IJQRM-05-2013-0075

Jones, T. O., \& Sasser, W. E. Jr. (1995). Why satisfied customers defect. Harvard Business Review, 73(6), 88-99.

Karolina, I. (2013). Customer Satisfaction Index-as a Base for Strategic Marketing Management. TEM Journal, 2(4), 327-331.

Kotler, P., Keller, K. E., Brady, M., Goodman, M., \& Hansen, T. (2009). Marketing management. London: Pearson Education Limited.

Ladhari, R., Pons, F., Bressolles, G., \& Zins, M. (2011). Culture and personal values: How they influence perceived service quality. Journal of Business Research, 64, 951-957. https://doi.org/10.1016/j.jbusres.2010.11.017

Lusch, R. F., \& Vargo, S. L. (2011). Service dominant logic: a necessary step. European Journal of Marketing, 45, 1298-1309. https://doi.org/10.1108/03090561111137723

McNeilly, K. M., \& Barr, T. F. (2006). I love my accountants-they're wonderful: understanding customer delight in the professional services arena. Journal of Services Marketing, 20(3), 152-159. https://doi.org/10.1108/08876040610665607

Merin, R. P., Hoffmann, A. O., \& Penning, J. M. (2013). Customer Satisfaction as a buffer against sentimental stock-price corrections. Marketing Letters, 24(1), 13-27. https://doi.org/10.1007/s11002-012-9219-9

Minocha, S., Dawson, L. H., Blandford, A., \& Millard, N. (2005). Providing value to customer in e-commerce environments: The customer's perspective. Contemporary Research in E-Marketing, 2. https://doi.org/10.4018/978-1-59140-824-6.ch006

National Communication Authority. (2011). The Mobile Number Portability. Retrieved April 2, 2014, from http://www.nca.org.gh

Nimako, S. G., Azumah, F. K., \& Donkor, F. (2010). Overall customer satisfaction in Ghana's mobile telecommunication networks: Implications for management and policy. ATDF Journal, 7(3/4), 35-49.

Novikova, K. (2009). A study of customer satisfaction factors and employee satisfaction in the hospitality industry. Southern Illinois University at Carbondale.

Oliver, R. L. (1980). A cognitive model of the antecedents and consequences of satisfaction decisions. Journal of Marketing Research, 17(4), 460-469. https://doi.org/10.2307/3150499

Oliver, R. L. (1993). Cognitive, affective, and attribute bases of the satisfaction response. Journal of Consumer Research, 20(3), 418-430. https://doi.org/10.1086/209358

Oliver, R. L. (1997). Satisfaction: A behavioural perspective on the consumer. New York: McGraw-Hill, Inc.

Oliver, R. L. (1999). Whence consumer loyalty? Journal of Marketing, 63(October), 33-44. https://doi.org/10.2307/1252099

Oliver, R. L., \& DeSarbo, W. S. (1988). Response determinants in satisfaction judgments. Journal of Consumer Research, 14(4), 495-507. https://doi.org/10.1086/209131

Palmatier, R. W., Dant, R. P., Grewal, D., \& Evans, K. R. (2006). Factors Influencing the Effectiveness of Relationship Marketing: A Meta-Analysis. Journal of Marketing, 70(4), 136-153. https://doi.org/10.1509/jmkg.70.4.136

Palmer, A. (2002). The Evolution of an Idea: An Environmental Explanation of Relationship Marketing. Journal of Relationship Marketing, 1(1), 79-94. https://doi.org/10.1300/J366v01n01_06 
Parasuraman, A., Zeithaml, V. A., \& Berry, L. L. (1985). A conceptual model of service quality and its implication for future research. Journal of Marketing, 49, 41-50. https://doi.org/10.2307/1251430

Parasuraman, A., Zeithaml, V. A., \& Berry, L. L. (1988). SERVQUAL Scale: a Multiple-Item Scale for Measuring Consumer Perception of Service Quality. Journal of Retailing, 64(1), 12-40.

Rauyruen, P., \& Miller, K. E. (2007). Relationship Quality as a Predictor of B2B Customer Loyalty. Journal of Business Research, 60, 21-31. https://doi.org/10.1016/j.jbusres.2005.11.006

Reichheld, F. F. (1996). The Loyalty Effect: the Hidden Force Behind Growth, Profits, and Lasting Value. Boston: Harvard Business School Press.

Reichheld, F. F., \& Sasser, J. (1990). Zero defection: quality comes to services. Harvard Business Review, 68(September-October), 105-111.

Reidenbach, R. E., \& Sandifer-Smallwood, B. (1990). Exploring perceptions of hospital operations by a modified SERVQUAL approach. Journal of Health Care Marketing, 10(4), 47-55.

Roberts, K., Varki, S., \& Brodie, R. (2003). Measuring the quality of relationships in consumer services: An empirical study. European Journal of Marketing, 37(1/2), 169-196. https://doi.org/10.1108/03090560310454037

Saleem, H., \& Raja, N. S. (2014). The impact of service quality on customer satisfaction, customer loyalty and brand image: Evidence from hotel industry of Pakistan. Middle-East Journal of Scientific Research, 19(5), 706-711. https://doi.org/10.9790/487X-1616117122

Santos, J., \& Boote, J. (2003). A theoretical exploration and model of consumer expectations, post purchase affective and affective behaviour. Journal of Consumer Behaviour, 3(2), 142-156. https://doi.org/10.1002/cb.129

Saunders, M., Lewis, P., \& Thornhill, A. (2009). Research methods for business students (5th ed.). Harlow: Prentice-Hall.

Spreng, R. A., \& Page, T. J. (2003). A test of alternative measures of disconfirmation. Decision Sciences, 34(1), 31-62. https://doi.org/10.1111/1540-5915.02214

Staples, D. S., \& Wong, I. (2002). Having expectations of information systems benefits that match received benefits; does it really matter? Information and Management, 40(2), 115-131. https://doi.org/10.1016/S0378-7206(01)00138-0

Tao, F. (2014). Customer Relationship Management based on Increasing Customer Satisfaction. International Journal of Business and Social Science, 5(5), 256-263.

Van Raaij, W. F. (1989). Economic news, expectations, and macro-economic behaviour. Journal of Economic Psychology, 10(12), 473-493. https://doi.org/10.1016/0167-4870(89)90039-1

Venkatesh, V., \& Goyal, S. (2010). Expectation disconfirmation and technology adoption: Polynomial modelling and response surface analysis 1. MIS Quarterly, 34(2), 281-303. https://doi.org/10.2307/20721428

Winer, R. S. (2001). Framework for customer relationship management. California Management Review, 43(4), 89-105. https://doi.org/10.2307/41166102

Wu, K. W., \& Ding, M. C. (2007). Validating the American customer satisfaction index model in the online context: An empirical study of U.S. consumer electronics e-tailers. International Journal of Business and Information, 2(2), 215.

Yang, Z. (2001). Measuring e-service quality and its linkage to customer loyalty. Dissertation Abstracts International. UMI No. 3034679.

Yoo, M., \& Bai, B. (2013). Customer Loyalty Marketing Research: A comparative approach between hospitality and business journals. International Journal of Hospitality Management, 166-177. https://doi.org/10.1016/j.ijhm.2012.07.009

Zeithaml, V. A., Berry, L. L., \& Parasuraman, A. (1993). The nature and determinants of customer expectations of service. Journal of Academy of Marketing Science, 21(1), 1-12. https://doi.org/10.1177/0092070393211001

Zeithaml, V. A., Berry, L. L., \& Parasuraman, A. (1996). The behavioral consequences of service quality. Journal of Marketing, 60, 31-46. https://doi.org/10.2307/1251929 


\section{Copyrights}

Copyright for this article is retained by the author, with first publication rights granted to the journal.

This is an open-access article distributed under the terms and conditions of the Creative Commons Attribution license (http://creativecommons.org/licenses/by/4.0/). 